\title{
Poetics of Un/feeling
}

\section{T. S. Eliot, Coleridge, Shakespeare ${ }^{1}$ VERONIKA RUTTKAY}

Abstract: This article contributes to the re-assessment of the role of affect in the writings of $T$. S. Eliot and argues that Eliot's thinking was shaped by earlier — notably Coleridgean - discussions of the feeling and writing self. It offers a dialogical reading of the two poet-critics, in which Coleridge's interpretation of Venus and Adonis and the typist scene of The Waste Land play central parts.

Who is the third who walks always beside you?

When I count, there are only you and I together

But when I look ahead up the white road

There is always another one walking beside you

Gliding wrapt in a brown mantle, hooded

I do not know whether a man or a woman

- But who is that on the other side of you?

(T. S. Eliot, The Waste Land 1l. 359-65)

According to the critical tradition and Eliot's own notes, this passage from The Waste Land is built upon Ernest Shackleton's account of a hallucinatory experience during his Antarctic expedition. It also subtly recalls the Biblical journey of the disciples to Emmaus, as described in Luke 24: 13-16 (Eliot, The Poems 1: 692-3). Each of these narratives contains a dramatic moment of dis/belief, which opens towards different resolutions: a mirage or a miracle. In Eliot's poem, however - a "lyrical epic" with its narrative links consistently missing (Craig 286-302) - closure does not arrive; the question insits: "Who is the third who walks always beside you?"

1 Supported by the ÚNKP 17-4 New National Excellence Program of the Hungarian Ministry of Human Capacities. 
According to Anthony Cuda, such ambivalent scenes of recognition are used by Eliot "both to explore and to enact the extremity of the soul's emotional response to the realization of its own limitations" (331). For this reason, the naming of such apparitions is both impossible and beside the point; more specifically, Cuda contends that these scenes convey what Eliot had already described in his essay on Andrew Marvell (1921) as "a recognition, implicit in the expression of every experience, of other kinds of experience which are possible" (Eliot, Selected Essays 303). It is based upon such underlying patterns and preoccupations that Cuda has argued for "the presence of a surprisingly unfamiliar poet lurking over Eliot's shoulder," one whose work is far less "detached" and far more invested in emotional upheavals than it is customarily believed about Eliot, "the accomplished proponent of classicism and orthodoxy" (362).

The present paper aims to contribute to the reassessment of Eliot's thinking about affect; however, I propose an alternative account of how feeling and detachment are configured, at least in some of his writings. In order to do this, I need to return to the much-discussed theme of Eliot's indebtedness to other poets, especially Shakespeare and Coleridge. Of course, intertextuality is germane to The Waste Land and is necessarily part of any interpretation of it. In an earlier discussion of "the third who walks always beside you," Maud Ellman, for instance, has highlighted the role of repetition and the Freudian death instinct, with the figure of the sexually and ontologically ambiguous "third" straddling the realms of life and death: "Neither absent nor present, this nameless third bodies forth a rhetoric of disembodiment, and figures the 'continual extinction' of the self. For the speaker rehearses his own death as he conjures up the writings of the dead, sacrificing voice and personality to their ventriloquy" (Ellman 275). Thus, Ellman connects the unknown "third" to the allusive method that informs Eliot's entire poem, which makes the subject continually appear and disappear on the shimmering surface of the text. This interpretation is worth remembering in the light of Guda's emphasis on emotional extremity, because it throws into sharp relief the question of the experiencing and/or speaking subject. Given that the "third" person lacks a coherent identity in Eliot's text, we may still ask: what about the first person? Where does Eliot's interest in depths of feeling leave the idea of the lyrical subject? The present paper argues that Eliot's thinking about such matters was shaped by earlier - notably Coleridgean - discussions of the feeling and the writing self, and suggests that a scene of ambivalent passion 


\section{POETICS OF UN/FEELING}

in Shakespeare's Venus and Adonis might have informed both poets' explorations. What I offer is essentially a dialogical reading of Eliot and Coleridge, in the hope that it may reveal new aspects of how these two poet-critics confronted the question of literary feelings, especially through Shakespeare's example. Meanwhile, I will also refer to recent theoretical work on affect in literature, most importantly, Rei Terada's Feeling in Theory: Emotion after the Death of the Subject (2003), whenever it seems to assist the clearer formulation of my concerns.

\section{Eliot and Coleridge}

Anne Stillman observes in an excellent essay that Eliot and Shakespeare “don't perform alone as a pair. They become a double-act only with a third term" (61). In this essay, I will be looking at what happens when that "third" is Coleridge, and it is worth noting that, similarly to the one "who walks always beside you," Coleridge is consistently associated with spectrality in Eliot's prose. In a chapter of The Use of Poetry and the Use of Criticism (1933), Eliot calls him a "haunted man": "for anyone who has ever been visited by the Muse is thenceforth haunted" - to which he adds something that had to be read from the start as a roundabout confession: "he was condemned to know that the little poetry he had written was worth more than all he could do with the rest of his life. The author of Biographia Literaria was already a ruined man. Sometimes, however, to be a 'ruined man' is itself a vocation" (69). The book elsewhere engages with Coleridge's Biographia Literaria (1817), not just as a chapter in literary history but in order to clarify Eliot's own theoretical positions. Some of this will boil down to a critique of notions we might label, by and large, "Romantic." Thus, stressing the importance of originality or the tendency to neglect the role of memory in the workings of the imagination, are clearly not compatible with Eliot's aims. About the much-quoted distinction between the fancy and the imagination, he drily remarks: "I wholly fail to appreciate this passage. My mind is too heavy and concrete for any flight of abstruse reasoning" (77). It is understandable if such words led scholars such as Eugenia Gunner to assume that Coleridge serves primarily as a foil to Eliot's own arguments, a Romantic antagonist for the self-professed Classicist, although, as Seamus Perry has made clear, the distinction is far from straightforward ("Eliot and Coleridge" 224-227). 
In the same book Eliot describes the workings of literary memory pointedly through the case of "Kubla Khan," in a passage that makes Coleridge the best illustration of Eliot's understanding of how a writer acquires his own personal tradition:

Coleridge's taste, at one period of life, led him first to read voraciously in a certain type of book, and then to select and store up certain kinds of imagery from those books. And I should say that the mind of any poet would be magnetised in its own way, to select automatically, in his reading (from picture papers and cheap novels, indeed, as well as serious books, and least likely from works of an abstract nature, though even these are aliment for some poetic minds) the material - an Image, a phrase, a word - which may be of use to him later. And this selection probably runs through the whole of his sensitive life. (Use of Poetry 78)

Here, Eliot deconstructs the critic with the help of the poet, showing that in spite of his apparent emphasis on originality, Coleridge is the best example to prove that writing is, and should be, a speaking through other voices, the voices of the dead. Characteristically, Eliot cites a line from Shakespeare-one that reverberates in The Waste Land - to illustrate the psychological process he stipulated behind the writing of "Kubla Khan": "The imagery of that fragment, certainly, whatever its origins in Coleridge's reading, sank to the depths of Coleridge's feeling, was saturated, transformed there - 'those are pearls that were his eyes'-and brought up into daylight again" (Use of Poetry 146). A few years earlier, Coleridge's creative process had been analysed by John Livingston Lowes in The Road to Xanadu: A Study in the Ways of the Imagination (1927), and Lowes's careful tracing of "the accumulated images from Coleridge's reading that formed associative hooks and eyes" (Maniquis 718) informed Eliot's own interpretation. Lowes did not accept the fancy/imagination distinction and argued that memory played a central role in creativity, while he also admitted that "there is no poem built upon associations without will, judgement, and disciplined selection” (quoted in Maniquis 718). Eliot criticizes Coleridge's work on precisely these grounds - "the poem has not been written" - but I think it at least possible that Coleridge himself would have concurred (after all, he published "Kubla Khan" only as a "psychological curiosity"). Similarly, he would have 


\section{POETICS OF UN/FEELING}

probably accepted Eliot's dictum that "even the finest line draws its life from its context," and therefore "Organisation is necessary as well as inspiration" (Use of Poetry 146). Indeed, when Eliot concludes his book by remarking that in Shakespeare's case we find an exceptional combination of literary inspiration with the power to rationally organize it (146-7), we may well suspect that this is not so much a case of a hypothetical Coleridge agreeing with Eliot, as much as Eliot agreeing with Coleridge.

The Coleridgean version of this insight, that is, his formulation of how Shakespeare combines "opposite or discordant qualities" is quoted with approval in the same book by Eliot: "the sense of novelty and freshness, with old and familiar objects; a more than usual state of emotion, with more than usual order; judgement ever awake and steady self-possession with enthusiasm and feeling profound or vehement" (qtd. in Use of Poetry 79; cf. Perry, "Coleridge's English Afterlife" 23). This is an excerpt from Chapter 14 of the Biographia Literaria, which Eliot cites via I. A. Richards, together with another passage from Chapter 15, on Venus and Adonis. For Eliot, these are instances of Coleridge reflecting on his own experiences of writing poetry and are highly instructive. Meanwhile, the edifice of Coleridge's transcendental theory offers, for the modern critic, a wholly different kind of evidence: it exemplifies what it means to have a passion for metaphysics. Earlier, Eliot had written extensively about that "passion," which, he believed, compromised Coleridge's achievement:

Coleridge's metaphysical interest was quite genuine, and was, like most metaphysical interest, an affair of his emotions. But a literary critic should have no emotions except those immediately provoked by a work of art - and these (as I have already hinted) are, when valid, perhaps not to be called emotions at all. Coleridge is apt to take leave of the data of criticism, and arouse the suspicion that he has been diverted into a metaphysical hare-and-hounds. His end does not always appear to be the return to the work of art with improved perception and intensified, because more conscious, enjoyment; his centre of interest changes, his feelings are impure. In the derogatory sense he is more "philosophic" than Aristotle. For everything that Aristotle says illuminates the literature which is the occasion for 


\section{VERONIKA RUTTKAY}

saying it; but Coleridge only now and then. It is one more instance of the pernicious effect of emotion. (Sacred Wood 12-13)

Before turning to the question of what, then, is Eliot's position with respect to the role of emotions - in what sense they are "pernicious," and how this is related to Coleridge - let me note that when Eliot says that Coleridge is illuminating "only now and then," he still accords him the second place in literary criticism after Aristotle, and, in English letters, the first. This explains the full import of the opening sentence of the essay — "The Perfect Critic" (1920) - according to which "Coleridge was perhaps the greatest of English critics, and in a sense the last" (Sacred Wood 1). When, in 1934, Eliot writes a survey of Shakespeare criticism from Dryden to Coleridge, he still "defines Coleridge as 'perhaps the greatest single figure in Shakespeare criticism down to the present day"' (Corcoran 67). Such remarks signal the modern writer's anxiety about his own position, revealed in the self-dramatizing final sentence of The Use of Poetry and the Use of Criticism that warns against the lure of too much theorizing: "The sad ghost of Coleridge beckons to me from the shadows" (156).

\section{UN/FEELING}

Let me now take a step back and consider the context of this dialogue in today's scholarship, while also clarifying why I think that the role of emotion, feeling, or affect, is of key significance. The literature on Eliot and Coleridge, or Eliot and Romanticism, not to mention on Eliot and Shakespeare, is extensive, and therefore I cite only one example here which conveniently demonstrates many of my concerns. Peter Holbrook in Shakespeare's Individualism (2010) devotes a chapter to "Eliot's rejection of Shakespeare," arguing along the way that

Eliot's anathematizing of the emotive literary criticism of the $19^{\text {th }}$ century has a clear cultural and political agenda. The $19^{\text {th }}$ century implied the twin pathologies of "exaltation of the personal and individual" and "emphasis upon feeling rather than thought"; and his antipathy towards this civilizational phase is one of the distinctive features of his criticism. (154) 


\section{POETICS OF UN/FEELING}

According to this account, Eliot is against Romanticism, against the dominance of feeling, and against the rise of the personal and the individual (in Holbrook's reading Eliot thought that the latter process began with Shakespeare). Other critics looking at the issues separately have already qualified some of these generalizations-I hope that my earlier points have also indicated, although not explored, the depth of Eliot's engagement with Coleridge. ${ }^{2}$ Before turning to the question of feeling, however, it is worth pondering for a moment why it is so easy to come to diametrically opposite conclusions about Eliot's sympathies. I think it has to do with an unusual reading style exhibited throughout Eliot's prose. It happens that he refers to a line or passage in order to vehemently criticize it - but this does not prevent him from citing something else by the same author which he, in turn, warmly admires. Helen Thaventhiran has recently argued that Eliot was 'an 'annotative' critic in a broader sense: a critic whose essays could take a form closer to that of commentary than argument, based around fragments of quotation" (34). Annotation is not meant to produce coherent interpretations; driven "by the vitality of accident, by 'chance encounters, appreciations and revulsions" (Thaventhiran 35), it allows for a certain inconsistency or open-endedness that seems to have suited Eliot's thinking style. In his essay on "Eliot and the Shudder" Frank Kermode makes a related point: "It is in his brilliant responses to [...] particular instances, rather than in his apprehensions of philosophical or theological wholeness, that I find Eliot at his most impressive as a critic." It seems to me that in Eliot's critical prose an author like Shakespeare or Coleridge (or Tennyson, who is in the focus of Kermode's article) is very close to being a bundle of texts or even lines, that enable all kinds of separate perceptions, and far less a unified 'person' than what we are still accustomed to as the organizing framework of modern literary criticism. In other words, Holbook's claim that Eliot rejects the "personal and individual" is probably the main point here, and it is related to both Eliot's reliance on intertextuality and to how he writes about affect.

For Eliot, of course, is not really "against feeling," in spite of his image as an icily intellectual modernist, guarded by the New Criticism and its injunctions against the Affective Fallacy. True, if we take a look at our quoted passages so far, we cannot

2 For detailed discussion, see Perry's "Eliot and Coleridge." Corcoran and Stillman offer rich accounts of Eliot's complicated interest in Shakespeare, while O'Neill shows that Eliot, while ostensibly in revolt against Romanticism, "is recognisably its heir" (200). Edward Lobb's study offers a thorough investigation of these interrelations, while Kermode's Romantic Image was the ground-breaking monograph on Modernist debts to Romanticism. 
ignore the reference to the "pernicious effect of emotion," or even the claim that "a literary critic should have no emotions." However, Eliot adds a curious caveat to the latter: "a literary critic should have no emotions, except those immediately provoked by a work of art - and these (as I have already hinted) are, when valid, perhaps not to be called emotions at all" (Sacred Wood 12-13). It is these peculiar kinds of emotions - or should we call them "un/emotions," "art-emotions" (Sacred Wood 57; 87), or maybe just "feelings"? — that are Eliot's primary "data of criticism." As he puts it in a later piece: "a valid interpretation [of a literary work] ... must be at the same time an interpretation of my own feelings when I read it" (On Poetry and Poets 113-4; cf. Shusterman 11). It is entirely in line with such a view that he criticizes Coleridge not because he 'feels', instead of, say, thinking, but because "his feelings are impure" - and they are claimed to have been made so precisely by his passion for thinking. Seen from this angle, Eliot suddenly starts to appear guiltier of 'emotivism' than most Romantic writers.

If we were to believe that such language occurs only in Eliot's later woks, and is absent from the so-called 'objectivist' essays published in The Sacred Wood (1920), we would be mistaken. In these writings, 'feeling' is everywhere, and is treated with great care and sophistication, for instance when Eliot writes that a poem "may be formed out of one emotion, or may be a combination of several; and various feelings, inhering for the writer in particular words or phrases or images, may be added to compose the final result. Or great poetry may be made without the direct use of any emotion whatever: composed out of feelings solely" (Sacred Wood 54). Here, Eliot implies a distinction between "feeling" and "emotion" reminiscent of later theories which tend to view "emotion" as "a psychological, at least minimally interpretive experience," and "affect" as its "physiological aspect," while "feeling" is often used as a broader term connoting "both physiological sensations (affects) and psychological states (emotions)" (Terada 4, cf. Leys 441-42). Much recent work focuses on "affects," described by Gregory Seigworth and Melissa Gregg as "visceral forces beneath, alongside, or generally other than conscious knowing, vital forces insisting beyond emotion" that "can serve to drive us toward movement, toward thought and extension, that can likewise suspend us (as if in neutral) across a barely registering accretion of force-relations, or that can even leave us overwhelmed by the world's apparent intractability" (1). Accounts like this make it very clear that such states - together with the concepts related to them - are fundamentally unstable 


\section{POETICS OF UN/FEELING}

and tend to slide into each other. Eliot himself provided formulations alive to their instabilities; in 1957 he wrote the following (cited by Cuda together with earlier similar passages): "It seems to me, that beyond the nameable, classifiable emotions and motives of our conscious life $[\ldots]$ there is a fringe of indefinite extent, of feeling which we can only detect, so to speak, out of the corner of the eye" (On Poetry and Poets 93, Cuda 334).

In this context, it becomes highly significant that Eliot's "impersonal theory of poetry" (Sacred Wood 53), as put forward in "Tradition and the Individual Talent" (1919), is in fact a theory of poetic emotion. The conclusion at which the final paragraph arrives is that "The emotion of art is impersonal" (Eliot, Sacred Wood 59). This theory, then, rests on the same conundrum as Eliot's comment, cited earlier, on the feelings proper to the critic (or, for that matter, his idea of the objective correlative): the concept of an emotion without an experiencing subject or "person" closely inter linked to it. The existence of such feelings is implied in some of Eliot's most memorable comments, which explains their curious grammar; for instance, when he claims about his favourite poets that their "words have often a network of tentacular roots reaching down to the deepest terrors and desires" (115). Neither the author's nor the reader's, and not even a fictitious character's, these feelings seem to travel with poetic language "mixing memory and desire" - or, as "Portrait of a Lady" has it, "Recalling things that other people have desired" (1. 42). To the wholly disinterested reader they are the text.

Readers who recognized the centrality of feeling to Eliot's criticism were at times deeply hostile to it. Terry Eagleton in his Literary Theory attributes to Eliot "the contempt for the intellect of any right-wing irrationalist" and, quoting Eliot himself, states: "The advantage of a language closely wedded to experience, for Eliot, was that it enabled the poet to bypass the deadly abstractions of rationalist thought and seize his readers by the "cerebral cortex, the nervous system, and the digestive tracts"" (40). It is not hard to see why Eagleton might have found such a stance objectionable. Ruth Leys in her critique of the "turn to affect" in cultural theory has also highlighted how recent approaches with close ties to neuroscience tend to privilege the pre-ideological and non-rational (Leys 437), which makes politically meaningful engagement difficult to imagine. From a very different standpoint, Wimsatt and Beardsley had voiced related anxieties already in the wake of World War II: "Emotion," as they note in "The Affective Fallacy," "has a well-known capacity to 


\section{VERONIKA RUTTKAY}

fortify opinion, to inflame cognition, and to grow upon itself in surprising proportions to grains of reason. We have mob psychology, psychosis, and neurosis" (38). It is as if the personal and political risks of free-floating emotion had also infected the poetic or critical engagement with them - and the reason for this seems to lie in the inherent capacity of feelings to undermine rationality and stable distinctions between self and other.

Eliot's interest in the construction and circulation of literary affect goes hand in hand with scepticism concerning the subject - a "disbelief" in its ability to know itself or indeed, in the possibility of arriving at any coherent description of it. In his dissertation on the philosophy of F. H. Bradley, the young Eliot "imagines the soul as a reservoir for the perceptual modes of experience that flood the mind and the senses simultaneously but are channelled into psychological foci that he calls 'points of view' or 'units of soul life' (Cuda 332). Four years later in "Tradition and the Individual Talent," Eliot is still "thinking about the irreducible plurality of these units," as Cuda points out (332), and he makes explicit the philosophical doubts informing his critical position:

The point of view which I am struggling to attack is perhaps related to the metaphysical theory of the substantial unity of the soul: for my meaning is, that the poet has, not a "personality" to express, but a particular medium, which is only a medium and not a personality, in which impressions and experiences combine in peculiar and unexpected ways. (Eliot, Sacred Wood 56)

The poet's soul or mind is "perhaps" not a unity. It might be de-centred, a medium receiving impressions and letting them be arranged into patterns of experience, which, however, have no stability over time and no regularities to conform to. Lacking "personality" to express in his work, this poet does not even have a unified or autonomous self to do the expressing, but is described as a "medium" - an inhuman or partly super-human entity, depending on whether we rely on science or the occult to contextualize the metaphor. Such an account of the poet's mind - of anyone's mind - is cognizant of the death of the transcendental subject that was theorized by various philosophies of late modernity. Eliot's emphasis on the impersonal nature of poetic emotion also comes close to what Terada calls "the 


\section{POETICS OF UN/FEELING}

nonsubjectivism of emotion" (7), that is, the view that emotion is not compatible with the idea of a centred subject.

The so-called "affective turn" in criticism has brought this side of Eliot to the attention of a number of critics. Apart from Anthony Cuda, Jean-Michel Rabaté has offered extensive analyses of Eliot's poetry in The Pathos of Distance: Affects of the Moderns. In a similar vein, Charles Altieri has highlighted "transpersonal" intensities in Eliot (161) and "a profound suspicion of all romantic expressivist notions of identity" (162), linking Eliot to Lacan. In the same collection, Tim Dean has argued that "[i]n place of the modern rationalist understanding of individual personality, Eliot substitutes a premodern - or postmodern - notion of the self as disunified and unbounded, a self that functions as a conduit not only for voices of the dead but perhaps for others' experiences too" (57). Such a way of putting it suggests that Eliot's understanding might be fruitfully studied in the light of not only what came later in philosophy, but also of earlier thought. While Dean goes back as far as Plato's Ion to trace Eliot's ancestors, Cairns Craig makes a compelling case for the poet's reliance on an essentially modern framework - associationism — which explored alternatives to the Cartesian and the transcendental self from the age of the Scottish Enlightenment to Modernism (286-308). Indeed, the Eliot for whom "Not only all knowledge, but all feeling, is in perception" (Sacred Wood 10), and who imagines poetic consciousness as a medium "in which impressions and experiences combine in peculiar and unexpected ways" (Sacred Wood 56), sounds strikingly close to David Hume, who wrote in his Treatise (1739): "But setting aside some metaphysicians of this kind, I may venture to affirm of the rest of mankind, that they are nothing but a bundle or collection of different perceptions, which succeed each other with an inconceivable rapidity, and are in a perpetual flux and movement" (252).

In The Use of Poetry and the Use of Criticism, Eliot makes a passing reference to David Hartley, the physician and thinker who aimed, like Hume, to describe the workings of the mind by applying Newton's experimental method, and who, in Eliot's words, "turns up at any moment with Coleridge" (77). At this point Eliot tries to account for the affective charge of an image he borrowed from Chapman, who in turn had found it in Seneca:

I suggest that what gives it such intensity as it has in each case is its saturation - I will not say with "associations," for I do not want 


\section{VERONIKA RUTTKAY}

to revert to Hartley - but with feelings too obscure for the authors even to know quite what they were. And of course only a part of an author's imagery comes from his reading. It comes from the whole of his sensitive life since early childhood. (The Use of Poetry 147-148)

Ron Bush notes that Eliot here follows I. A. Richards in discounting "old associationists" like Hartley (726). Nevertheless, this too is an associationist interpretation in all but name, especially if we bear in mind that even for "old" theorists, the realm of associations was rarely confined to conscious thought. Hartley wanted to describe the physiology of nervous vibrations corresponding to mental processes, while his one-time disciple Coleridge found in the poet of Venus and Adonis "[a]n endless activity of Thought, in all the possible associations of Thought with Thought, Thought with Feelings, or with words, or of Feelings with Feelings, \& words with words" (Lectures 1: 66). Such multifarious connections between word, thought, and feeling also underlie the process described by Eliot, by which an image encountered in reading might become intertwined with early memories or unconscious feelings. Eliot's sense of the mind's associative nature probably also informs what Ron Bush calls his "passionate allusions": in his writings, feeling seems to travel and be transformed through the circuits of intertextuality. In what remains of my paper, I will look at an earlier elaboration of impersonal feeling in English criticism, Coleridge's commentary on Venus and Adonis, which, as we have already seen, Eliot knew well, and then I will conclude with its potential relevance to Eliot's poetry and especially The Waste Land.

\section{Coleridge and Shakespeare}

Scholarly accounts of the reception history of Venus and Adonis tend to describe a downward curve, starting with the poem's great popularity among all sorts of readers, and then describing its fall into revulsion and neglect (Kolin 10-15; Duncan-Jones and Woudhuysen 78-79). Its eroticism was, of course, a problem. Catherine Belsey sums up the complications as follows: "Love's object is a boy who looks like a girl, and who is in one sense too young for the difference to matter; its modes of address are at once absurd and lyrical and tragic. Passion is contrary, contradictory; 'love is,' the text affirms, 'wise in folly, foolish witty"' $(1.838,53)$. In the century following the poem's first publication, the taxonomy of love and lust, which is offered but 


\section{POETICS OF UN/FEELING}

not sustained in Shakespeare (cf. Belsey), came to be applied more rigidly, with the result that Venus and Adonis had to be perceived as either pornography or moral allegory. Editions of Shakespeare tended to leave it out altogether and although Edmund Malone included it in his own edition, he could not help complaining of its "wearisome circumlocution" (Kolin 11-12). This, however, already points towards the other problem with Venus and Adonis, which, from the later $18^{\text {th }}$ century, became as significant an objection as that of immorality. The poem did not conform to the norms of sincere emotional expression that became so central to the literature of sensibility and romanticism. J. W. Lever sums up the situation succinctly: "On moral grounds [the poem] was deemed too sensual yet artistically it was considered too cold" (19). The charge of coldness was expressed most notably in William Hazlitt's Characters of Shakespeare's Plays (1817):

It has been the fashion of late to cry up on our author's poems, as equal to his plays: this is the desperate cant of modern criticism. [...] The two poems of Venus and Adonis and of Tarquin and Lucrece appear to us like a couple of ice-houses. They are about as hard, as glittering, and as cold. (347-8)

Shakespeare is described here as shockingly unfeeling, interested only in his own virtuoso display:

The author seems all the time to be thinking of his verses, and not of his subject, - not of what his characters would feel, but of what he shall say ... Sentiment is built up upon plays of words; the hero or heroine feels, not from the impulse of passion, but from the force of dialectics. (348-9)

It is significant that Hazlitt is attacking "modern criticism" along with Shakespeare's narrative poems: his immediate target was almost certainly Coleridge, who had been giving public lectures in London during the same years as Hazlitt himself. As early as 1808, Coleridge spoke warmly about Venus and Adonis; he repeated and developed his points in 1811-12 and 1813-14, and finally published his observations in the Biographia Literaria in the year in which Hazlitt's Characters also appeared. From 


\section{VERONIKA RUTTKAY}

the start, Coleridge relied on Venus and Adonis to demonstrate his general conception of what poetry is, or should be, and to show what he thought of Shakespeare's character as a poet. Importantly, he did not choose to argue that the poem was, in fact, a sincere expression of Shakespeare's feeling or a record of his own experiences in any sense. That would be the course taken by Arthur Symons in his 1885 introduction to Venus and Adonis (Holbrook 152-3), whose approach, in turn, is criticized by Eliot in "The Perfect Critic." Coleridge, rather, is astonished by what he tentatively calls Shakespeare's "alienation" and "utter aloofness" (Biographia 2: 22), and celebrates him for choosing a topic that had nothing to do with his own affections.

Romantic writing has been known for its investment in feelings virtually from the moment of its inception; however, until recently, "this issue was dead, or worse, a critical liability" (3) - as Joel Faflak and Richard Sha put it in their introduction to Romanticism and the Emotions. Interest in embodied experience and gender, the intense study of medical and scientific texts, and a re-assessment of philosophical positions such as empiricism or associationism have led to critical articulations that broach the subject of 'romantic feelings' in meaningful new ways. Coleridge, like most critics of the age, relied on a range of terms in connection with affect, as when he wrote in 1808 that "Strong Passions commend figurative Language \& act as stimulants" (Lectures 1: 86) - a claim that evokes the medical discourse of John Brown and his followers ("Stimulants"), together with the new rhetoric of the later $18^{\text {th }}$ century (developed variously by Kames, Priestly and others). However, a peculiarity of Coleridge's thought is that, although he believes in passion's stimulating power informing poetic creation, his view of poetry is non-expressivist, at least when he is thinking of Shakespeare. According to him, Shakespeare was able to speak "the language of passion" while he remained uninvolved; through figures of great "force \& propriety" (Lectures 1: 267), he created emotional states that were radically improper to him. It may be noted that the feelings in question could be "im-proper" in more than one way; as Coleridge's notes reveal, he hesitated to read out in the lectureroom one of the more sexually suggestive passages from Venus and Adonis. In 1808, he quoted the description of the Hare to support his point about the poet's "Love of natural Objects," noting that "there is indeed a far more admirable description precedent, but less fitted for public recitation," meaning the love-pursuit of the horses (Venus and Adonis 2.259-318). By 1811, he seems to have got over his worries (Notebooks 3247 and note), but the reference is again absent from the Biographia. This suggests 


\section{POETICS OF UN/FEELING}

that Coleridge insisted on the "utter aloofness of the Poet's own feelings, from those of which he is at once the painter and the analyst" (Biographia 2: 22), at least in part for reasons of propriety. Contrasting Shakespeare with other writers who degrade "the passion of Love into the Struggles of an animal ap Impulse" (Lectures 1: 243), he wanted to refute any possible charges of immorality against the author of Venus and Adonis. Indeed, he writes that Shakespeare "has here precluded all sympathy with the Desire by dissipating the readers [sic] attention" into elaborate imagery and witty reflection - turning even the "animal impulse" (in a double sense) into an object of disinterested contemplation (Biographia 2: 22).

However, as Terada points out, not feeling something is sometimes itself a feeling - in cases like that "anesthesia hurts" (14), as in Keats's line, quoted by her, "The feel of not to feel it." In Venus and Adonis, the speaker's lack of sympathy with his characters' passionate plight, in conjunction with his keen observation and the characters' own diminished understanding of themselves, produces a unique intensity that Coleridge saw as central to Shakespeare's poetry. The Biographia states that "the legitimate language of poetic fervour [is] self-impassioned" (2: 65) - in other words, it is generated by the very activity of poetic creation, without being dependent on the outside world or the poet's personal feelings. Shakespeare is the greatest example of this: like the Spinozistic deity or a veritable Proteus, he "becomes all things, yet for ever remaining himself" (2: 27-8). Such paradoxical formulations can be seen as Coleridge's way of uniting his sense of the decentred self of the artist with an equally strong need for conscious control and self-possession. It is at this point that Coleridge's Shakespeare comes closest to Eliot's impersonal artist. In a lecture note on Venus and Adonis, Coleridge claims that Shakespeare writes "as if he were of another planet," and in the Biographia we find the following:

It is throughout as if a superior spirit more intuitive, more intimately conscious, even than the characters themselves, not only of every outward look and act, but of the flux and reflux of the mind in all its subtlest thoughts and feelings, were placing the whole before our view; himself meanwhile unparticipating in the passions, and actuated only by that pleasurable excitement, which had resulted from the energetic fervor of his own spirit in so vividly exhibiting, what it had so accurately and profoundly contemplated. (2: 21) 


\section{VERONIKA RUTTKAY}

The author-figure Coleridge is at pains to describe resembles nothing so much as Tiresias in The Waste-Land: unparticipating, yet paradoxically conscious, even more so than the participants, of everything "Enacted on this same divan or bed" in the typist scene of "The Fire Sermon." Similarly to him-her ("old man with wrinkled dugs"), Coleridge's Shakespeare is "more intuitive than the Parties themselves" of every thought and feeling, "the flux and reflux of the mind." We may also note that this "superior spirit," while not involved in the passions of the lovers, is actuated by a "pleasurable excitement and emotion" which results from the activity of his own expressive powers - such "poetic feeling," in Coleridge's parlance, is the minimal but sufficient affective justification for poetic language, the "excitement" or "stimulant" that makes poetry possible.

\section{THE WASTE LAND AND VENUS AND ADONIS}

Reading Coleridge's elaboration of this conception of Shakespeare in tandem with modernist writing brings out certain features of it that tend to remain hidden in accounts focusing on the romantic context alone. For one thing, the implied androgyny. Coleridge did not dwell on this, but certainly Virginia Woolf picked up on his remark that "a great mind must be androgynous" (Table Talk 2: 190-1), as we can see from A Room of One's Own (1929), where her thoughts leap from Coleridge to Shakespeare as a matter of course. ${ }^{3}$ Recent studies have engaged more extensively with gender ambiguities in Eliot, often returning to an early poem - first published in Poems Written in Early Youth (1967) - that offers a striking enactment of transpersonal affect: "The Death of Saint Narcissus" (e.g. Dean; Rabate 40). The opening lines were going to be reworked for The Waste Land ("Come under the shadow of this gray rock-"), but something quite astonishing happens in the later parts, which makes the protagonist a more extreme version of Tiresias (cf. Comley):

First he was sure that he had been a tree,

Twisting its branches among each other

And tangling its roots among each other.

3 "He meant, perhaps, that the androgynous mind is resonant and porous; that it transmits emotion without impediment; that it is naturally creative, incandescent and undivided. In fact, one goes back to Shakespeare's mind as the type of the androgynous, of the man-womanly mind" (Woolf 71). 


\section{POETICS OF UN/FEELING}

Then he knew that he had been a fish

With slippery white belly held tight in his own fingers,

Writhing in his own clutch, his ancient beauty

Caught fast in the pink tips of his new beauty.

Then he had been a young girl

Caught in the woods by a drunken old man

Knowing at the end the taste of his own whiteness

The horror of his own smoothness,

And he felt drunken and old. (2.21-32)

This, too, is a portrait of the artist - according to Ted Hughes, "the first portrait, perhaps the only full-face portrait, of Eliot's genius" (cf. Schuchard). While Hughes takes this in the direction of the shamanic experience of the unity of all being, it is also a variation on Coleridge's Protean poet in whom sympathetic identification coexists with "unparticipating" aloofness: the poet who "passes into all the forms of human character and passion, the one Proteus of the fire and the flood" (Biographia 2: 27). In what remains of my paper, I will briefly suggest that the connection between Coleridge's view of the impersonal poet and Eliot's Tiresias may amount to more than a passing resemblance.

As we have seen, Coleridge described Shakespeare's genius through the discussion of Venus and Adonis in a section of the Biographia cited with approval in The Use of Poetry and the Use of Criticism. Not much later in A Companion to Shakespeare Studies (1934) Eliot again referred to this analysis in connection with Shakespeare's "most profound, energetic and philosophic mind" (298-9). In light of this, it is surprising that Venus and Adonis itself has so rarely been considered as a source for Eliot's "lyrical epic," in spite of the fact that the Adonis myth is mentioned in Eliot's own notes, and that Shakespeare's source, Ovid, is recognized as a major influence (but cf. Laroque who does suggest a connection). As we have also seen, a double experience of rape was crucial to Saint Narcissus's loss of personhood, and it is a similar scene which triggers the appearance of Tiresias in the geometric centre of the The Waste Land, in the middle of "The Fire Sermon": 


\section{VERONIKA RUTTKAY}

The time is now propitious, as he guesses,

The meal is ended, she is bored and tired,

Endeavours to engage her in caresses

Which still are unreproved, if undesired.

Flushed and decided, he assaults at once;

Exploring hands encounter no defence;

His vanity requires no response,

And makes a welcome of indifference. (2.235-242)

The consciousness in control of this passage and the lines surrounding it - the famous double sonnet embedded in The Waste Land - is intimately aware of both the male and the female experience, and even of something more, which follows from the external point of view and is the source of its troubling pathos. Let me juxtapose to this three stanzas from Venus and Adonis that describe another assault:

Now quick desire hath caught the yielding prey,

And glutton-like she feeds, yet never filleth.

Her lips are conquerors, his lips obey,

Paying what ransom the insulter willeth;

Whose vulture thought doth pitch the price so high

That she will draw his lips' rich treasure dry.

And having felt the sweetness of the spoil,

With blindfold fury she begins to forage;

Her face doth reek and smoke, her blood doth boil,

And careless lust stirs up a desperate courage,

Planting oblivion, beating reason back,

Forgetting shame's pure blush and honour's wrack.

Hot, faint, and weary, with her hard embracing,

Like a wild bird being tamed with too much handling,

Or as the fleet-foot roe that's tired with chasing,

Or like the froward infant still'd with dandling, 


\section{POETICS OF UN/FEELING}

He now obeys, and now no more resisteth,

While she takes all she can, not all she listeth. (2.547-564)

The rhythms and intensities in these lines have such resonance with Eliot's typist scene that would justify a closer comparison. Some of this follows from the way the sonnet form informs both texts, with special features like the combination of feminine and masculine rhymes. On the thematic level, the typist scene has more conventionally assigned gender roles and therefore it has to be seen as transforming Shakespeare's transformation of Ovid. However, all three poems have to do with fertility rituals gone wrong. But if Eliot is indeed rewriting Shakespeare's Venus and Adonis in this section (which I think he is doing), the presence hovering at the edges of the text must be that of Coleridge.

\section{WORKs Gited}

Altieri, Charles. "Theorizing emotions in Eliot's poetry and poetics." In Gender, Desire, and Sexuality in T. S. Eliot. Eds. Laity, Cassandra, Nancy K. Gish. Cambridge: Cambridge University Press, 2004. 150-172.

Belsey, Catherine. "Love as Trompe l'oeil: Taxonomies of Desire in Venus and Adonis." In Shakespeare in Theory and Practice. Edinburgh: Edinburgh University Press, 2007. 34-53. Originally published in Shakespeare Quarterly 46:3 (Fall I995). 257-76.

Bush, Ron. "Intensity by Association: Eliot's Passionate Allusions." Modernism/ Modernity, 20.4 (Nov 2013), 709-727.

Coleridge, Samuel Taylor. Biographia Literaria. Vol. I-2. Eds. Engell, James, Walter Jackson Bate. Princeton: Princeton University Press, I983.

-. Lectures I808-I8I9: On Literature. Vol. I-2. Ed. Foakes, R. A. Princeton: Princeton University Press, 1987.

-. The Notebooks. Vol. I-4. Eds. Coburn, Kathleen (vol. I-3), Merton Christensen (vol. 4). Princeton: Princeton University Press, I957-I990.

-. Table Talk.Vol. I-2. Ed. Woodring, Carl. Princeton: Princeton University Press, I990.

Comley, Nancy R. "From Narcissus to Tiresias: T. S. Eliot's Use of Metamorphosis." The Modern Language Review, 74:2 (Apr. 1979). 28I-286. 
Corcoran, Neil. Shakespeare and the Modern Poet. Cambridge: Cambridge University Press, 2010.

Craig, Cairns. Associationism and the Literary Imagination: From the Phantasmal Chaos. Edinburgh: Edinburgh University Press, 2007.

Cuda, Anthony J. "Who Stood over Eliot's Shoulder?" Modern Language Quarterly, 66:3 (Sept. 2005). 329-364.

Dean, Tim. “T. S. Eliot, famous clairvoyante." In Gender, Desire, and Sexuality in T. S. Eliot. Eds. Laity, Cassandra, Nancy K. Gish. Cambridge: Cambridge University Press, 2004. 43-65.

Eagleton, Terry. Literary Theory: An Introduction. Oxford: Blackwell, I983.

Eliot, T. S. The Poems of T. S. Eliot. Eds. Ricks, Christopher, Jim McCue. Vol. I-2. Baltimore: Johns Hopkins University Press, 2015.

-. The Sacred Wood: Essays on Poetry and Criticism. London: Methuen, 1920; 1960.

-. Selected Essays. $2^{\text {nd }}$ rev., edition. London: Faber and Faber, 1934.

-. "Shakespearean Criticism." In A Companion to Shakespeare Studies. Eds. Harley, Granville-Barker, G. B. Harrison. Cambridge: Cambridge University Press, I934. 287-304.

-. The Use of Poetry and the Use of Criticism. London: Faber and Faber, 1933; 1948.

-. On Poetry and Poets. London: Faber and Faber, 1957.

Ellmann, Maud. "A Sphynx without a Secret." In T. S. Eliot. The Waste Land: Authoritative Text, Contexts, Criticism-A Norton Critical Edition. Ed. North, Michael. London and New York: W. W. Norton and Company, 200I. 258-275. Originally published: Ellmann, Maud. The Poetics of Impersonality: Eliot and Pound. Brighton: Harvester, 1987.

Faflak, Joel and Richard C. Sha. "Introduction: Feeling Romanticism." In Romanticism and the Emotions. Eds. Faflak, Joel, Richard C. Sha. Cambridge: Cambridge University Press, 2014. I-I8.

Gunner, Eugenia M. T. S. Eliot's Romantic Dilemma: Tradition's Anti-Traditional Elements. London and New York: Routledge, 1985; 2015.

Hazlitt, William. Characters of Shakespeare's Plays. London, I8I7.

Holbrook, Peter. Shakespeare's Individualism. Cambridge: Cambridge University Press, 2010.

Hume, David. A Treatise of Human Nature. Eds. Selby-Bigge, P. H. Nidditch. Oxford: Clarendon Press, 1978. 
Kermode, Frank. "Eliot and the Shudder." London Review of Books 32.9 (I3 May 20I0), I3-16. www.lrb.co.uk.

-. Romantic Image. London and New York: Routledge, I957; 2002.

Kolin, Philip C. "Venus and/or Adonis Among the Critics." In Venus and Adonis: Critical Essays. Ed. Kolin, Philip C. New York and London: Routledge, 1997.3-65. Laroque, François. "Will in the 'Waste Land:' Shakespeare and Eliot Revisited." In Forum for World Literature Studies, 6:I (March 20I4). I08-II9.

Lever, J. W. "The Poems - Twentieth-Century Studies in Shakespeare's Songs, Sonnets and Poems." Shakespeare Survey Vol. I5 (1962): The Poems and Music. Ed. Nicoll, Allardyce. I8-30.

Lobb, Edward. T. S. Eliot and the Romantic Critical Tradition. London and New York: Routledge, 1981.

Maniquis, Robert M. "Writing about Coleridge." In The Oxford Handbook ofSamal Taylor Coleridge. Ed. Burwick, Frederick. Oxford: Oxford University Press, 2009. 713-730.

O’Neill, Michael. "Romantic and Victorian Poetry." In T. S. Eliot in Context. Ed. Harding, Jason. Cambridge: Cambridge University Press, 20II. 200-2Io.

Perry, Seamus. “Coleridge's English Afterlife." In The Reception of S. T. Coleridge in Europe. Eds. Shaffer ,Elinor, Edoardo Zuccato. London, etc.: Bloomsbury, 2007. I4-I6.

—. "Eliot and Coleridge." In Coleridge's Afterlives. Eds. Vigus, James, Jane Wright. Basingstoke and New York: Palgrave Macmillan, 2008. 224-25I.

Rabaté, Jean-Michel. The Pathos of Distance: Affects of the Moderns. London, etc.: Bloomsbury Academic, 2016.

Schuchard, Ronald. "T. S. Eliot and Ted Hughes: Shamanic Possession." South Atlantic Review 76:3 (Summer 20II), 5I-73.

Seigworth, Gregory J. and Melissa Gregg. "An Inventory of Shimmers." In The Affect Theory Reader. Eds. Seigworth, Melissa Gregg. Durham and London: Duke University Press, 2010. I-25.

Shakespeare, William. Shakespeare's Poems. Venus and Adonis, The Rape of Lucrece and the Shorter Poems. Eds. Duncan-Jones, Katherine, H. R. Woudhuysen. London: Thomson Learning, 2007.

Shusterman, Richard. T. S. Eliot and the Philosophy of Criticism. London: Duckworth, I988. 
Stillman, Anne. "T. S. Eliot.” In Great Shakespeareans XII: Joyce, T.S. Eliot, Auden, Beckett. Ed. Poole, Adrian. London and New York: Continuum, 2012. 57-IO4. Tereda, Rei. Feeling in Theory: Emotion after the Death of the Subject. Cambridge, Mass: Harvard University Press, 2003.

Thaventhiran, Helen. Radical Empiricists: Five Modernist Close Readers. Oxford: Oxford University Press, 2015.

Wimsatt, W. K. Jr and M. C. Beardsley. "The Affective Fallacy." The Sewanee Review 57 (1949): 3I-55.

Woolf, Virginia. A Room of One's Own-The Shakespeare Head Press Edition. Eds. Bradshaw, David, Stuart N. Clarke. Wiley Blackwell, 2015.

\section{Contributor Details}

Veronika Ruttkay is senior lecturer at Eötvös Loránd University, Budapest, where she teaches mostly 18th and 19th-century English Literature. She has published several articles and book chapters on English Romantic writers and Shakespeare, as well as their Hungarian reception and translation. 